\title{
Occupational Satisfaction of E-Rickshaw Drivers with Reference to Itahari-Nepal
}

\author{
Arjun Rai ${ }^{1}$
}

\begin{abstract}
Seeing many electric rickshaws plying on plain rural and urban areas has become a common sight these days. Empirically, it can also be seen that many overseas returnees are taking up the occupation as an e-rickshaw driver as a means of financing their family needs. In the backdrop of this context, this research paper attempts to explore the challenge \& opportunities associated with their occupation, their intention to switch from their current occupation, satisfaction of erickshaw drivers of Itahari, Nepal. This study used a structured questionnaire to collect primary data from 95 electric rickshaw drivers of Itahari. For data analysis, the researcher used Statistical Package for Social Science- 20. Descriptive and inferential statistical tools were used in the study. The findings of the study shows that, on average the e-rickshaw drivers are satisfied with their current occupation, majority of them do not have intention to switch occupation. The commonest problems faced by them are "the condition of the road" and "traffic problem".
\end{abstract}

Keywords: E-Rickshaw, occupational satisfaction, profit, employment, switching occupational intention.

\section{Introduction:}

\subsection{Background of Study:}

These days, the modalities of developments have changed from mere indicative or sectorial "development" to overall "sustainable development". Development in its true sense connotes sustainable one that last longer. United Nations Academic Impact defines Sustainable development requires an integrated approach that takes into consideration environmental concerns along with economic development. Out of many approaches to sustainable development, one of the key focuses is on energy security. Sarakikya, H. (2015), remarked that energy security is a socio-economic and political factor that contributes to sustainable development (SD) in any nation. With reference to United Nations' Sustainable Development Goals (SDGs) (2017), access to reliable, affordable, sustainable, and modern energy to all people is one of the sustainable development goals. Furthermore, energy resources can be nonrenewable or renewable; however, currently, the world is dominated by the usage of nonrenewable energy such as fossil fuels. These are unsatisfactory because of their depletion and environmental concerns, Bishoge, Zhang, and Mushi, (2018, p.1)

1 Lecturer, Faculty of Management, Mahendra Multiple Campus, Dharan, Tribhuvan University, Nepal. Email: chhiwatpang@gmail.com 
United Nations, in its report entitled "Energy for a Sustainable Future" published in (2010) claimed that energy is at the heart of most critical economic, environmental and developmental issues facing the world today. In addition to that, United Nations in the same paper highlighted the importance of clean energy through the subsequent quote, "clean, efficient, affordable and reliable energy services are indispensable for global prosperity. Developing countries in particular need to expand access to reliable and modern energy services if they are to reduce poverty and improve the health of their citizens, while at the same time increasing productivity, enhancing competitiveness and promoting economic growth."

On the one hand the sustainability movement is gaining momentum; on the other hand, the price of fossil fuel is increasing remarkably. Heinberg, (2011), commented that the cost of developing a new barrel of oil's worth of production capacity has increased dramatically in recent years. In 2000, the oil industry remained profitable with prices pivoting around $\$ 20$ per barrel. Today it is estimated that oil prices of $\$ 60$ to $\$ 80$ per barrel are required in order to incentivize new exploration and production in many prospective regions. Besides that, the concerns for global warming caused by Ozone layer depletion are increasing exponentially. One of the major underlying causes of global warming is attributed to the use of fossil fuels. To support this proposition, various scholars and international organizations like Souza, Ballester, Cruz, Chum, Dale, Dale, (2017), Owusu, Sarkodie, (2016), and International Energy Agency (in their respective reports) claimed that the use of non-renewable energy is considered as the principal provider to climate change, which is about $60 \%$ of the total greenhouse gas emissions; therefore, decrease of carbon concentration is a key goal in long-term climate objectives. In the backdrop of this context, to curb the usage rate of fossil fuel to mitigate the damage to the environment, Government of Nepal, Ministry of Population and Environment in its policy draft entitled "Renewable Energy Subsidy Policy, 2073" published in (2016), announced that Nepal government had been working to formulate and implement clean energy policies to reduce dependence on traditional and imported energy by increasing access to renewable energy for improving the livelihoods of people and create employment opportunities especially in the rural areas. In the background of Nepal government's policy to promote clean energy to reduce poverty, incorporate clean energy policy to promote employment opportunity, growing global concerns for environmental issues, and soaring price of fossil fuel, electric rickshaw seems to be a panacea for solving all aforementioned problems.

Today one can witness many electric rickshaws plying on the rural and urban roads. Many people have taken up this occupation as a means of livelihood. Every occupation or profession has certain challenges. Thus, one can hypothesize that even electric rickshaw (hereinafter referred as e-rickshaw) drivers also must have certain challenges. To support this proposition, a statement made by a non-government organization called "Bikalpa" on its blog referred to a story of an e-rickshaw driver of Biratnagar. Which reads; 
Kapil Sharma is a middle aged labour who like numerous other Nepalese returned back from Qatar after his health was adversely affected due to the working conditions there. He invested his hard earned money to buy an electric rickshaw so that he could earn a living by staying with his family. After he had brought the rickshaw he was aghast to find that the Municipality of Biratnagar had unilaterally fixed a quota for the number of electric rickshaws. So he could never get his electric rickshaw registered. Soon he was regularly bullied by the traffic police and many times he had to pay large amount as bribes. Like many others he had to drive hiding from the police so that he could pay his loan installments on time. There are several such stories in Biratnagar. (para 1)

Kapil Sharma's case may just be an anecdote, representing many untold ordeals of other erickshaw drivers. This paper aims at uncovering different facets of problems and opportunities faced by other e-rickshaw drivers of Itahari, Nepal.

\subsection{Research objectives:}

The following are the major objectives of this research.

a To examine the occupational satisfaction (job satisfaction) of e-rickshaw drivers of Itahari, Nepal.

b To investigate into the switching intentions of e-rickshaw drivers of Itahari, Nepal.

c To find out average daily earning of e-rickshaw drivers of Itahari, Nepal.

d To identify the major occupational challenges faced by e-rickshaw drivers of Itahari, Nepal.

e To find out average monthly profit of e-rickshaw drivers of Itahari, Nepal.

\subsection{Research problem:}

Abuhashesh, Dmour, and Masa'deh, (2019, p.1) asserted that most people would agree that an occupation is an essential part of life, individuals view work differently. Further, Abuhashesh, \& et al (2019), opineed that some people consider their occupation simply as a means to monetary compensation, while others consider it to be what defines their social status. People choose different occupations either by their interests or compulsion. Those people who tend to choose particular occupation with their interest, tend to be satisfied, Wiener \& Klein, (1978). Chen (2006), quoted that when people are satisfied with their occupation their intention to switch to other occupations decreases. In the context of this specific study does the assertion of author hold valid? This paper focuses on answering this question. Based on the above mentioned research problem, this research attempts to answer the following research questions.

a Are e-rickshaw drivers of Itahari, Nepal, satisfied with their current occupation?

b Do e-rickshaw drivers of Itahari have intention to switch their occupation? 
c What is the average daily earning of e-rickshaw drivers of Itahari, Nepal?

d What are the major occupational challenges faced by e-rickshaw drivers of Itahari, Nepal?

e What is the average monthly profit of e-rickshaw drivers of Itahari, Nepal?

\subsection{Research hypothesis:}

Research hypothesis is a conjectural statement which is tested after the data collection. In other words, a research hypothesis is an assumption about research findings, which are tested upon the collection and, analysis of the data. The hypothesis may be true or false, which will be tested using different statistical tools. In this study the researcher formulated the following null hypothesis.

$H_{0} 1$ : There is no significant difference in the average profit among the e-rickshaw drivers.

$H_{0}$ 2: There is no significant difference in the average monthly expenses of E-Rickshaw drivers.

$H_{0}$ 3: There is no significant association between occupational satisfaction of E-rickshaw drivers and their recommendation to others to start the same occupation.

\subsection{Significance of Research:}

This research article has the following significances.

a As this study aims to find out the occupational problems faced by e-rickshaw drivers, the findings can be used by the concerned officials such as traffic offices, financial institutions to address the problems of e-rickshaw drivers.

b The findings of this study can be referred by other individuals before choosing this occupation. For example, this study will shed lights on the average daily earning, monthly earning, monthly expenses to operate e-rickshaw and these findings can be of immense use to those individuals who are planning to start the profession of e-rickshaw driver.

c This study is important to those who are already in this occupation. This study aims to find out average monthly expenses to operate e-rickshaw and, average battery life (a key component of e-rickshaw). Therefore, such information will be of great importance to those who are already in this occupation.

\subsection{Literature review:}

Locke (1976) has defined job satisfaction as the pleasurable emotional state resulting from the appraisal of one's occupation or occupational experiences. Around the sphere, it is an established fact that a person with a high level of occupational satisfaction shows positive 
attitude towards the occupation, while a person who is dissatisfied with the occupation has a negative attitude. Occupational satisfaction can be considered as a general feeling about the occupation or as a related constellation of attitudes about various aspects or facets of the occupation (Kovach, 1977); French (1982) and Tziner and Vardi (1984), define occupational satisfaction as an effective response or reaction to a wide range of conditions or aspects of one's work such as pay, supervision, working conditions, and/or the work itself. There are some occupation related factors which can ensure occupational satisfaction such as supervision, pay, promotion opportunities, coworkers and so forth, the nature of the work itself generally emerges as the most important occupational facet (Judge \& Church, 2000; The source of this occupational satisfaction not only arises from the occupation but also from the other factors like- work environment (both physical and social), relationship with supervisors \& peers, corporate culture, managerial style. Occupational satisfaction of employees and their intention to switch to other occupations are inversely related. Implying that when employees are satisfied with their current occupations, their intention to quit and take up another occupation decreases Chen, (2006).

Clarification of the Terms:

E-rickshaw: an online search engine called "Quora" defines e-rickshaw as, small vehicles, with three wheels and use electric power from batteries to run. They use an electric motor as engine which draws electric power from the rechargeable batteries installed in the rickshaw body. Thus, in this context of study e-rickshaw are the three wheeled vehicles which are propelled by electric motor using electric power supplied from the rechargeable batteries installed in it. Schyns, Torka, \& Gössling, (2007) define switching intention or turnover intention as an employee's intention to voluntarily change occupations or companies. In this context, switching intention of e-rickshaw drivers means, their willingness to change their occupation.

\subsection{Limitations of the study:}

Like other researches, even this research has certain limitations, in terms of scope, tools, and other analytical issues. This research has following limitations.

a The study considered the population of e-rickshaw drivers of Itahari, Nepal only. Whereas; there are many other e-rickshaw drivers all over Nepal. The result would have been comprehensive, if other e-rickshaw drivers from other parts of Nepal were also included in the study.

b This study aimed at exploring the current status of e-rickshaw drivers, the study does not compare economic status of e-rickshaw drivers before starting the occupations. This study does not investigate the impact of their occupation on their socio-economic status. 
c In this study, the researcher used descriptive and few other inferential statistical tool. The researcher used only quantitative technique in this study. The study would have been better, if qualitative techniques were used.

\subsection{Research gap:}

Many research have been conducted in the field of sustainable energy, however, sufficient studies have not been done in this specific area i.e. electric rickshaw driver's occupational satisfaction. These days, many youths are opting for this profession as a means to finance their family. In spite of electric rickshaw's great contribution to generate self employment in Nepalese context, the scholars seem to underestimate its magnum, and thereby ignore the necessity for conducting research related to e-rickshaw's stakeholders. Thus, this research aims at exploring many facets of e-rickshaw drivers, such as; their satisfaction, their income status, prior experience etc.

\section{Method \& Materials:}

This research is descriptive in nature. A structured questionnaire was used to collect the primary data from 95 e-rickshaw drivers of Itahari, Nepal to find out their occupational satisfaction, their previous field of occupational experience, their average monthly profit (Total earning - total operating expenditures), the major challenges faced by them and their intention to switch to the other occupations. In this research, the researcher's philosophical stance is positivist. The researcher used quantitative data analysis. (Neuman, 2010), asserts that quantitative technique has the ability to provide rigorous and precise measures. For analyzing the primary data, Statistical Package for Social Science -20 was used. This study used both descriptive and inferential statistics. In this study, Goodness of Fit and Chi-Square Tests were used for inference.

\section{Results and Discussion}

The table 1 depicts gender profile of the respondents under the study. Out of 95 respondents 92.6\% respondents are male and, $7.4 \%$ are female e-rickshaw drivers. Higher number of male e-rickshaw drivers compared to female drivers may be attributed to Nepalese social perceptions towards gender based occupations. However, unless further researches are conducted to explore the reasons behind the reluctance of women to choose this occupation, such assertions cannot be validated.

Table 1 Gender Profile of E-rickshaw Drivers

\begin{tabular}{lll}
\hline & $\mathrm{N}$ & Valid Percent \\
\hline Male & 88 & 92.6 \\
Female & 7 & 7.4 \\
Total & 95 & 100 \\
\hline
\end{tabular}


The table 2 shows that out of 95 respondents, $90.5 \%$ ( 86 respondents) respondents' age is above 20 and $9.5 \%$, (9 respondents) respondents' age is 20 or below 20. Table exhibits that less numbers of younger peoples have chosen the occupation of driving e-rickshaw. This fact propels further questions such as; why are younger people less attracted to this occupation in Nepal? To answer such questions further investigations must be carried out by scholars.

Table 2 Age Profile of E-rickshaw Drivers

\begin{tabular}{lll}
\hline Age groups & N & Valid Percent \\
\hline 20 or below 20 & 9 & 9.5 \\
above 20 & 86 & 90.5 \\
Total & 95 & 100 \\
\hline
\end{tabular}

The table 3 exhibits the educational profile of e-rickshaw drivers. Out of 95 respondents, $62.1 \%$, respondents' educational qualification is under S.LC (SEE), and 27.4\% respondent's educational qualification is S.L.C. or equivalent. Only $10.5 \%$ respondents have higher secondary level (Plus2) of qualification. The data shows that, the lower the educational qualification, fewer the number of people who have chosen this occupation. This fact raises a question "does educated workforce have negative perceptions towards this profession? Further researches can be carried out to answer this question.

Table 3 Educational Profile of E-rickshaw Drivers

\begin{tabular}{lll}
\hline Level of education & $\mathrm{N}$ & Valid Percent \\
\hline Under SLC or SEE & 59 & 62.1 \\
SLC or SEE & 26 & 27.4 \\
Plus 2 & 10 & 10.5 \\
Total & 95 & 100 \\
\hline
\end{tabular}

Table 4 shows the funding sources of e-rickshaw drivers' business. Out of 95 respondents, 52 i.e. $54.7 \%$ e-rickshaw drivers have purchased e-rickshaw in full down payment i.e. fully cash and 43 , i.e. $45.3 \%$, of e-rickshaw drivers have used financing facility from different financial institutions. As the more owners of e-rickshaw have purchased their rickshaws on full cash payment, this fact intrigues few questions, such as; did the owners purchase their rickshaws due to unavailability of financing facilities from financial institutions? Or due to higher interest rates charged by the banks? Or did they buy on full cash because of low financial awareness? Such questions must be probed by policy makers and other concerned authorities. 


\begin{tabular}{|c|c|c|}
\hline & Frequency & Valid Percent \\
\hline Fully Cash & 52 & 54.7 \\
\hline Financing & 43 & 45.3 \\
\hline Total & 95 & 100 \\
\hline
\end{tabular}

Table 5 shows the number of e-rickshaw drivers, who recommend others to start the same. The table shows that out of 95 respondents, 63 respondents $(66.3 \%)$ recommended others to start the same occupation; whereas; 32 respondents $(33.7 \%)$ would not recommend the occupation to others.

Table 5 Recommend Others to This Occupation

\begin{tabular}{lll}
\hline & Frequency & Valid Percent \\
\hline Yes & 63 & 66.3 \\
No & 32 & 33.7 \\
Total & 95 & 100 \\
\hline
\end{tabular}

Table 6 shows the major occupational challenges faced by the e-rickshaw drivers. Out of 95 respondents 1 respondent did not disclose information regarding the faced problem. Thus, there is 1 missing case. According to table 6, out of 94 respondents, 24 of the respondents (25.5\%) consider the condition of the road as their occupational challenges, followed by the "traffic" as the next occupational challenge. Traffic is considered to be occupational challenge by $24.5 \%$ respondents. The rate of "fare" is least considered occupational challenge. Out of 94 respondents only 2 respondents i.e. $2.1 \%$ consider the "fare" as occupational challenge. Around the same number of e-rickshaw drivers considered the traffic and the condition of the road as the most problematic factor in their occupation.

Table 6 Challenges Faced by E-Rickshaw Drivers

\begin{tabular}{lll}
\hline & Frequency & Valid Percent \\
\hline Condition of Road & 24 & 25.5 \\
No challenges & 11 & 11.7 \\
Traffic & 23 & 24.5 \\
Road and Traffic & 1 & 1.1 \\
Competition & 24 & 25.5 \\
Weather & 4 & 4.3 \\
Parking & 3 & 3.2 \\
Fare & 2 & 2.1 \\
Others & 2 & 2.1 \\
Total & 94 & 100 \\
\hline
\end{tabular}

Missing case $=1$

Key question that arises here is despite, all the vehicle owners timely payment of road tax, renewal of permit of the vehicles to the concerned authorities, why is the condition of the road 
so feeble? Traffic personnel's duty is supposed to be facilitative instead of hindering, but still why do the e-rickshaw drivers consider the traffic police as a hindering factor in their occupation? Further studies may be carried out to answer such questions.

Table 7 Satisfaction E-rickshaw Drivers with Their Occupation

\begin{tabular}{lll}
\hline & Frequency & Valid Percent \\
\hline Yes & 70 & 74.5 \\
No & 24 & 25.5 \\
Total & 94 & 100 \\
\hline
\end{tabular}

Missing case $=1$

Table 7 presents the number of e-rickshaw drivers who are satisfied or dissatisfied with their current occupation. There is one missing case. Thus, out of 94 respondents 70 respondents $(74.5 \%)$ are satisfied with their current occupation, whereas; 24 respondents $(25.5 \%)$ were dissatisfied with their occupation.

Table 8 Gender-wise Occupational Satisfaction

\begin{tabular}{llll}
\hline & \multicolumn{2}{l}{ Satisfaction with occupation } & Total \\
Gender & Yes & No & 87 \\
\hline Male & 65 & 22 & 7 \\
Female & 5 & 2 & 94 \\
Total & 70 & 24 & \\
\hline
\end{tabular}

Missing case $=1$

Table 8 shows gender-wise occupational satisfaction of e-rickshaw drivers. Out of 95 respondents, 1 is the missing case. The table depicts that, out of 87 male respondents, 65 respondents are satisfied with their current profession and, 22 respondents are dissatisfied with their occupation. Similarly, out of 7 female e-rickshaw drivers, 5 respondents are satisfied and 2 respondents are dissatisfied with their occupation.

Table 9 Qualification-wise Occupational Satisfaction

\begin{tabular}{|c|c|c|c|c|c|}
\hline \multirow{3}{*}{ Qualification } & \multicolumn{4}{|c|}{ Satisfaction with occupation } & \multirow{3}{*}{ Total } \\
\hline & \multicolumn{2}{|c|}{ Yes } & \multicolumn{2}{|c|}{ No } & \\
\hline & $\mathrm{F}$ & $(\%)$ Yes & $\mathrm{F}$ & (\%) No & \\
\hline Under SLC or SEE & 44 & 74.58 & 15 & 25.42 & 59 \\
\hline SLC or SEE & 20 & 80.00 & 5 & 20.00 & 25 \\
\hline Plus 2 & 6 & 60.00 & 4 & 40.00 & 10 \\
\hline Total & 70 & 74.47 & 24 & 25.53 & 94 \\
\hline
\end{tabular}

Missing case $=1$

Table 9 shows the occupational satisfaction of the respondents based on the level of qualifications. According to the table out of 59 respondents, whose qualification is under S.L.C 
/ S.E.E, 44 respondents are satisfied with the occupation and 15 are dissatisfied. Furthermore, out of 25 respondents whose qualification is S.L.C / S.E.E, 20 respondents are satisfied and 5 are dissatisfied with their occupation. Similarly, out of 10 respondents with Plus-2 level qualification, 6 respondents are satisfied and 4 are dissatisfied with their profession.

Table 10 Previous Occupation-wise Occupational Satisfaction Satisfaction with occupation

\begin{tabular}{llll}
\hline Previous Occupation & Yes & No & Total \\
\hline Overseas employment & 27 & 11 & 38 \\
Employment in Nepal & 11 & 4 & 15 \\
Agriculture & 21 & 3 & 24 \\
Others & 9 & 6 & 15 \\
Total & 68 & 24 & 92 \\
\hline
\end{tabular}

Missing case $=3$

Table 10 exhibits occupational satisfaction of respondents with respect to their previous occupational fields. Out of 38 overseas returnees, 27 of them are satisfied with their occupation and 11 are dissatisfied. Similarly out of 15 respondents, who had employment opportunity in Nepal, 11 are satisfied and 4 are dissatisfied with their occupation. Furthermore, out of 24 respondents who were employed in agricultural sector, 21 respondents are satisfied and 3 are dissatisfied, and other 15 respondents, whose previous occupational category is "others", 9 of them were satisfied and 6 were dissatisfied.

Table 11 Age-wise Occupational Satisfaction

Satisfaction with occupation

\begin{tabular}{llll} 
Age & Yes & No & Total \\
\hline 20 or below 20 & 6 & 3 & 9 \\
above 20 & 64 & 21 & 85 \\
Total & 70 & 24 & 94 \\
\hline
\end{tabular}

Missing case $=1$

Table 11 presents age-wise occupational satisfaction of e-rickshaw drivers. The table shows that, out 9 respondents whose age is 20 years or below, 6 respondents are satisfied with their occupation and 3 are dissatisfied. Similarly, out of 85 respondents with age category "above 20 years", 64 of them are satisfied and 21 are dissatisfied with their occupation. 
Table 12 Intention of E-rickshaw Drivers to Switch the Occupation

\begin{tabular}{lll}
\hline & Frequency & Valid Percent \\
\hline Yes & 32 & 33.7 \\
No & 63 & 66.3 \\
Total & 95 & 100 \\
\hline
\end{tabular}

Table 12 depicts the intention of e-rickshaw drivers' intention to switch to other occupations. Out of 95 e-rickshaw drivers, 63 respondents $(66.3 \%)$ have no intention of switching their current occupation, even if they are paid the similar salary, which they are currently earning in their occupation. But 32 respondents $(33.7 \%)$ have intention to change their occupation, if they get opportunity to earn more than what they are currently earning.

Table 13 Duration of E-rickshaw Drivers in the Occupation

\begin{tabular}{lll}
\hline & Frequency & Valid Percent \\
\hline 1-2 years & 29 & 30.5 \\
2-3 years & 17 & 17.9 \\
3-4 years & 3 & 3.2 \\
above 4 years & 11 & 11.6 \\
below 1 Year & 35 & 36.8 \\
Total & 95 & 100 \\
\hline
\end{tabular}

Table 13 depicts the duration in the occupation of e-rickshaw drivers. Out of 95 respondents $36.8 \%$ i.e. 35 respondents are new entrants to the occupation, the second highest number of respondents who are in the occupation for last 1-2 year accounts for $30.5 \%$. The pattern of duration in the occupation seems weaken as the year passes. It can be seen from the table that longer the duration of occupation, less people are found to be in their occupation. The table shows that there are only 11 out of 95 respondents who have been in the occupation for more than 4 years. The table reveals that, longer the year in the profession, fewer the number of people in that occupation, is it so because, as they remain the field for longer period, the monotony with the occupation also increases, or as they remain in the occupation for longer period, do they find out the negative aspects of the occupation? Further researches can be conducted to find out the reasons behind few people remaining in this field in long term.

Table 14 Gender-wise Duration of Occupation of E-Rickshaw Drivers

\begin{tabular}{lllll}
\hline \multicolumn{5}{c}{ Group of Duration of occupation } \\
Gender & Below 1 Year & 1-2 Year & 2 Years or Above & Total \\
\hline Male & 31 & 26 & 31 & 88 \\
Female & 4 & 3 & 0 & 7 \\
Total & 35 & 29 & 31 & 95 \\
\hline
\end{tabular}


Table 14 shows gender-wise duration in the occupation of e-rickshaw drivers. Out of 95 , male e-rickshaw drivers have been in the occupation relatively for longer period compared to female e-rickshaw drivers. The table clearly portrays that 31 male respondents are in their occupation for 2 or more than 2 years and below one year.

Table 15 Age-wise Duration in Occupation

\begin{tabular}{lllll}
\hline & \multicolumn{3}{l}{ Number of year in the occupation } & Total \\
Age groups & Less than 1 Year & 1-2 Year & 2 or more year & \\
\hline 20 or below 20 & 5 & 3 & & 9 \\
Above 20 & 30 & 26 & 30 & 86 \\
Total & 35 & 29 & 31 & 95 \\
\hline
\end{tabular}

Table 15 shows duration of occupation of e-rickshaw drivers on the basis of their age group. The table shows that out of 95 respondents, 30 respondents with age more than 20 years have been in the occupation for less than 1 year category and more than 2 years in the occupational category. Only one respondent whose age is less or equal to 20 have been in the profession for more than 2 years. Perhaps it implies that younger people tend to switch occupations frequently. However, further researches must be carried out to validate such assumptions.

Table 16 Group of Average Daily Earning (In Rs.)

\begin{tabular}{lllll}
\hline Gender & Below 500 & $500-$ 1000 Daily & Above 1000 & Total \\
\hline Male & 4 & 54 & 30 & 88 \\
Female & 1 & 4 & 2 & 7 \\
Total & 5 & 58 & 32 & 95 \\
\hline
\end{tabular}

Table 16 exhibits comparative average daily earning of male and female e-rickshaw drivers. The table shows that male e-rickshaw drivers' average daily earning is higher than the average daily earning of female e-rickshaw drivers. Out of 95 e-rickshaw drivers 54 respondents average daily earning is in between Rs 500-1000, whereas; in the same earning category only 4 female respondents have the level of earning. Similarly, in average daily earning category of "above 1000", 30 male e-rickshaw drivers fall under this earning category. Number of female e-rickshaw drivers whose average daily earning less than Rs. 500 is 1 and the highest number of female whose average daily earning is Rs. 500-1000 is four.

Table 17 Age-wise Average Daily Earning of E-Rickshaw Drivers (In Rs.)

\begin{tabular}{lllll}
\hline Age & $500-1000$ Daily & Above 1000 & Below 500 & Total \\
\hline 20 or below 20 years & 4 & 5 & 0 & 9 \\
Above 20 Years & 54 & 27 & 5 & 86 \\
Total & 58 & 32 & 5 & 95 \\
\hline
\end{tabular}


Table 17 shows average daily earning of e-rickshaw drivers on the basis of age groups. Out of 86 e-rickshaw drivers under the age group of "above 20 years", 27 of them male average daily earning above Rs. 1000. Similarly, under the same age group 54 e-rickshaw drivers' average daily earning is in between Rs. 500-1000. Out of 9 respondents under " 20 or less than 20" age group, 5 e-rickshaw drivers' earning is above Rs. 1000 and 4 of them have average daily earning in between Rs. 500-1000. Under this age group no respondent has average daily earning less than Rs. 500.

Table 18 Qualification-wise Average Daily Earning of E-Rickshaw Drivers (In Rs.)

\begin{tabular}{lllll}
\hline & \multicolumn{2}{l}{ Group of Average Daily Earning } & & \\
Qualification & $500-$ 1000 Daily & Above 1000 & Below 500 & Total \\
\hline Under SLC or SEE & 36 & 21 & 2 & 59 \\
SLC or SEE & 17 & 7 & 2 & 26 \\
Plus 2 & 5 & 4 & 1 & 10 \\
Total & 58 & 32 & 5 & 95 \\
\hline
\end{tabular}

Table 18 shows average daily earning of respondents on the basis of their respective educational qualification. Out of 95 respondents, 59, 26, and 10 e-rickshaw drivers have under SEE / S.L.C, S.L.C and Plus 2 level of qualification respectively. Out of 59 respondents with "below S.LC" educational qualification, 36 of them have average daily earning of Rs. 5001000. Similarly, 21 of them have average daily earning above Rs. 1000 and 2 respondents have average daily earning less than Rs. 500. The table shows that comparatively, respondents with lower educational qualification have higher rate of average daily earning.

Table 19 Previous Occupation-wise Average Daily Earning of E-Rickshaw Drivers (In Rs.)

\begin{tabular}{lllll}
\hline & \multicolumn{4}{l}{ Group of Average Daily Earning } \\
Previous Occupations & $500-1000$ & Above 1000 & Below 500 & Total \\
\hline Overseas employment & 27 & 9 & 2 & 38 \\
Employment in Nepal & 9 & 6 & 1 & 16 \\
Agriculture & 14 & 10 & 0 & 24 \\
Others & 6 & 7 & 2 & 15 \\
Total & 56 & 32 & 5 & 93 \\
\hline
\end{tabular}

Missing cases $=2$

Table 19 shows average daily earning of e-rickshaw drivers on the basis of their previous occupations. The table shows that out of 93 respondents, 38 of respondents are foreign employment returnees. Out of 38 respondents with overseas employment experience, 27 respondents' average daily earning is in between Rs. 500-1000, and 9 of respondents under this occupational experience category make average daily earning of above Rs. 1000 and 2 respondents under this category have average daily earning less than Rs. 500. The next higher 
average earning earners are the respondents are those, whose previous occupational experience was in agriculture. Under agriculture previous occupational category, out of 24, 14 respondents' average daily earning is in between Rs. 500-1000, followed by 10 respondents with average daily earning above Rs. 1000. Previous occupational experience category "others" are lower in number in every "average daily earning" categories.

Table 20 Average Monthly Profit on the Basis of Mode of Payment (In Rs.)

\begin{tabular}{lll}
\hline Funding source & Mean & $\mathrm{N}$ \\
\hline Fully Cash & $24,800.00$ & 50 \\
Financing & $27,272.73$ & 44 \\
Total & & 94 \\
\hline
\end{tabular}

Missing case $=1$

Table 20 presents comparative average monthly earning on the basis of mode of payment, while buying e-rickshaw. Out of 95 respondents, one is missing case. Thus, out of $94 \mathrm{e}-$ rickshaws, 50 owners purchased e-rickshaw on full cash mode and 44 owners financed the erickshaw. The e-rickshaw owners, who used financing to own e-rickshaw, their average monthly profit is comparatively higher than those owners, who bought the e-rickshaw on full cash payment. Those, who used financing facility to buy e-rickshaw on average, make profit of Rs. 27,272.73; compared to those who bought e-rickshaw in full cash, make average monthly profit of Rs. $24,800.00$

Table 21 Gender-wise Average Monthly Profit (In Rs.)

\begin{tabular}{lll}
\hline Gender & Mean & N \\
\hline Male & $26,091.95$ & 87 \\
Female & $24,285.71$ & 7 \\
Total & & 94 \\
\hline
\end{tabular}

Missing case $=1$

Table 21 depicts average monthly profit of male and female e-rickshaw drivers. Out of 95 respondents, 1 is missing. Thus, out of 94 e-rickshaw drivers, 87 male rickshaw drivers' average monthly profit is Rs. 26,091.95, which is higher than the average monthly profit of female e-rickshaw drivers, whose average monthly profit is Rs. $24,285.71$

Table 22 Educational Qualification-wise Average monthly Profit (In.Rs.)

\begin{tabular}{lll}
\hline Education & Mean & $\mathrm{N}$ \\
\hline Under SLC or SEE & $26,779.66$ & 59 \\
SLC or SEE & $24,400.00$ & 25 \\
Plus 2 & $25,000.00$ & 10 \\
Total & & 94 \\
\hline
\end{tabular}

Missing case $=1$ 
Table 22 exhibits average monthly profit of respondents on the basis of their educational qualifications. Out of 94 respondents, 59 respondents' educational qualification is under S.L.C and their average monthly profit is Rs. $26,779.66$, followed by the next higher average monthly profit Rs. 25,000.00 of the respondents with plus 2 level of qualification. The least earners in terms of qualification is S.L.C (Rs. $24,400 /$ month)

\section{Testing of hypothesis}

$\mathrm{H}_{0} 1$ : There is no significant difference in the average profit among the e-rickshaw drivers. To test this hypothesis, a goodness of fit test was conducted. The following table 23 test statistics represents the test statistics for goodness of fit.

Table 23 Test Statistics for goodness of fit (Average profit of E-Rickshaw Drivers)

\begin{tabular}{ll}
\hline & Group of Average monthly Profit \\
Chi-Square & $51.404^{\mathrm{a}}$ \\
\hline Df & 2 \\
Asymp. Sig. & 0.000 \\
\hline
\end{tabular}

a. 0 cells $(0.0 \%)$ have expected frequencies less than 5 . The minimum expected cell frequency is 31.3 .

Statistical interpretation: table 23 shows Chi-square test for goodness of fit. The Chi-square value is $=51.404$ with degree of freedom $=2$. The observed $p$. value $0=0.000$ which is less than expected $p$. value (0.05). Therefore, the null hypothesis is rejected.

Interpretation: There is significant difference in the average monthly profit of e-rickshaw drivers. [Since: $\mathrm{p}$. value $=0.000<0.05$ ]

$\mathrm{H}_{0}$ 2: There is no significant difference in the average monthly expenses of e-rickshaw drivers. To test this hypothesis, a goodness of fit test was conducted. The following table 21 test statistics represents the test statistics for goodness of fit.

Table 24 Test Statistics for goodness of fit (Average monthly expenses of E-Rickshaw Drivers)

\begin{tabular}{ll}
\hline & Average monthly expenses (in Rs. \\
\hline Chi-Square & $68.085^{\mathrm{a}}$ \\
Df & 1 \\
Asymp. Sig. & 0 \\
\hline
\end{tabular}

a. 0 cells $(0.0 \%)$ have expected frequencies less than 5 . The minimum expected cell frequency is 47.0 .

Statistical interpretation: table 24 shows Chi-square test for goodness of fit. The Chi-square value is $=68.085^{\mathrm{a}}$ with degree of freedom $=1$. The observed $\mathrm{p}$. value $0=0.000$ which is less than expected p. value (0.05). Therefore, the null hypothesis is rejected. 
Interpretation: There is significant difference in the average monthly expenses of e-rickshaw drivers. [Since: $\mathrm{p}$. value $=0.000<0.05$ ]

$\mathrm{H}_{0} 3$ : There is no significant association between occupational satisfaction of E-rickshaw drivers and their recommendation to others to start the same occupation. To test this hypothesis, Chisquare test was used. The Chi-square test statistics is presented in the following table 26.

Table 26 Chi-Square Tests

\begin{tabular}{llll}
\hline & Value & df & Asymptotic Significance (2-sided) \\
\hline Pearson Chi-Square & $43.344^{\mathrm{a}}$ & 1 & 0.000 \\
Continuity Correction $^{\mathrm{b}}$ & 40.095 & 1 & 0.000 \\
Likelihood Ratio $^{\text {Fisher's Exact Test }}$ & 43.696 & 1 & 0.000 \\
Linear-by-Linear Association & 42.883 & 1 & 0.000 \\
N of Valid Cases & 94 & & \\
\hline
\end{tabular}

a. 0 cells $(0.0 \%)$ have expected count less than 5 . The minimum expected count is 7.91 .

b. Computed only for a $2 \times 2$ table

Table 26 depicts Pearson's Chi-Square 43.344, and observed $\mathrm{p}$. value $=0.000$, which is less than expected $p$. value (0.05). Therefore, the null hypothesis is rejected.

Interpretation: since the observed p. value is 0.000 which is less than 0.05 , this implies there is significant association between e -rickshaw drivers' occupational satisfaction and the recommendation they make to others to start the same occupation as e-rickshaw drivers. [Since: p. value $=0.000<0.05$ ]

\section{Conclusion:}

The study shows that $74.5 \%$ respondents were satisfied with their current occupation, whereas; $25.5 \%$ were dissatisfied. Gender-wise occupational satisfaction analysis shows that out of 87 male respondents, 65 respondents are satisfied with their current profession and, 22 respondents were dissatisfied with their occupation. Similarly, out of 7 female e-rickshaw drivers, 5 respondents were satisfied and 2 respondents were dissatisfied with their occupation. Out of 38 overseas returnees, 27 of them are satisfied with their occupation and 11 are dissatisfied. Similarly out of 15 respondents, who had employment opportunity in Nepal, 11 are satisfied and 4 are dissatisfied with their occupation. Furthermore, out of 24 respondents who were employed in agricultural sector, 21 respondents were satisfied and 3 are dissatisfied with their occupation. Regarding the intention of e-rickshaw drivers' intention to switch the occupation, $66.3 \%$ have no intention of switching to other occupations, even if they are paid the similar salary, which they are currently earning in their occupation. But 32 respondents (33.7\%) have intention to change their occupation if they get opportunity to earn more than what they are 
currently earning. Regarding the most commonly faced problem out of 95, only 94 responded this question. The data revealed that $25.5 \%$ consider the condition of the road as their occupational challenges, and $24.5 \%$ consider 'traffic' as the next occupational challenge. Comparative average daily earning of male and female e-rickshaw drivers shows that male erickshaw drivers' average daily earning is higher than the average daily earning of female erickshaw drivers. Qualification-wise daily earning of drivers shows that comparatively the respondents with lower educational qualification have higher rate of average daily earning. Furthermore, analysis shows that, overseas returnee drivers' average daily earning is highest amongst other previous experience categories. Comparative analysis of the average monthly profit of e-rickshaw drivers is found to be different significantly. Similarly test statistics revealed that there is significant difference in the average monthly expenses of e-rickshaw drivers. Chi-Square test to examine the association between drivers' occupational satisfaction and their likelihood of recommending others to choose e-rickshaw driving profession shows that there is significant relationship between the tested variables. Analysis revealed that 63 respondents $(66.3 \%)$ would recommend others to start the same occupation; whereas; 32 respondents (33.7\%) would not recommend the occupation to others. Concluding remark: The findings of the study shows that on average the samples under the study seem to be satisfied with their current occupation. However, there are areas which require further studies. The discussion section in the data analysis highlights the areas for further research.

\section{References}

Abuhashesh, M. Dmour, R. A., and Masa'deh, R., (2019)," Factors that affect Employees Job Satisfaction and Performance to Increase Customers' Satisfactions", Journal of Human Resources Management Research, Vol. 2019 (2019), Article ID 354277, DOI: $10.5171 / 2019.354277$

Bishoge, O. K., Zhang, L., and Mushi W. G., (2018) The Potential Renewable Energy for Sustainable Development in Tanzania: A Review, Clean Technologies. , 1, 6; doi:10.3390/cleantechnol1010006

Chen, C., F., (2006). Job satisfaction, organizational commitment, and flight attendants' turnover intentions: A note. Journal of Air Transport Management, 12(5), 274276.doi:10.1016/j.jairtraman.2006.05.001

Energy for a Sustainable Future; The Secretary-General's Advisory Group on Energy and Climate Change-Summary Report and Recommendations 28 April 2010 New York, 
available at

https://www.un.org/chinese/millenniumgoals/pdf/AGECCsummaryreport\%5B1\%5D.p df [Date Accessed : August 7, 2019]

Fisher, D. (2000). Mood and Emotions while working: missing pieces of job satisfaction? Journal of Organizational Behavior, 21, 185-202.

Government of Nepal Ministry of Population and Environment (2016). Renewable Energy Subsidy Policy, 2073 BS available on https://www.aepc.gov.np/uploads/docs/2018-0619_RE\%20Subsidy\%20Policy,\%202073\%20(English).pdf [Date Accessed: August 7, 2019]

Greenberger, J., Baron, R.A. (1993). Behavior in organizations: Understanding and managing the human side of work, 4thedition, Boston: Allyn and Bacon.

Heinberg, R. (2011), Rising Cost of Fossil Fuels and the Coming Energy Crunch https://oilprice.com/Energy/Energy-General/Rising-Cost-Of-Fossil-Fuels-And-TheComing-Energy-Crunch.html\# [Date Accessed : August 4 2019]

Herzberg, F., Mausner, B., Peterson, R. O., Cap well, D. F. (1957). Job Attitudes: Review of Research and Opinion (Pittsburgh, Pa.: Psychological Service of Pittsburgh).

https://academicimpact.un.org/content/sustainability [Date Accessed: August 7, 2019]

https://bikalpaanalternative.org/2016/there-is-a-need-for-a-concrete-policy-on-e-rickshaw-innepal/

International Energy Agency. Energy Climate and Change World. Energy Outlook Special Report. 2015. Available online: https://www.iea.org/publications/freepublications/publication/ WEO2015SpecialReportonEnergyandClimateChange.pdf [Date Accessed: August 7, 2019]

Kovach, K.A. (1977). Organizational size, job satisfaction, absenteeism, and turnover. Washington, D.C. University Press of America.

Locke, E. A. (1976). “The Nature and Causes of Job Satisfaction”. Handbook of Industrial and

McNally, R., (1984). Job Satisfaction. In Social psychology and Organizational Behavior. New York; John Willy \& Sons. Organizational Psychology, 1297-349. M. D. Dunette, ed. Chicago 
Owusu, P.A., Sarkodie, S. (2016), A Review of Renewable Energy Sources, Sustainability Issues and Climate Change Mitigation. Vol. 3, 1-15.

Sarakikya, H. (2015) Renewable energy policies and practice in Tanzania: Their contribution to Tanzania economy and poverty alleviation. International Journal of Energy Power 4, 333

Schyns, B., Torka, N., \& Gössling, T. (2007). Turnover intention and preparedness for change. Career Development International, 12(7), 660-679.doi:10.1108/13620430710834413

Souza, G.M., Ballester, M.V.R., Cruz, C.H.; Chum, H.; Dale, B.; Dale, V.H. (2017), The Role of Bio-Energy in a Climate-Changing World. Environmental Development , 23, 57-64

The United Nations. Goal 7: ENSURE Access to Affordable, Reliable, Sustainable and Modern Energy for All. Sustainable Development Goals. 2017. Available online:https://www.un.org/sustainabledevelopment/ energy/

Tziner, A.E., \& Vardi,Y. (1984), Work satisfaction and absenteeism among social workers: The role of altruistic values, Work and Occupations, 11(4), pp 461-470.

Universalizing Clean Energy in Nepal: A Plan for Sustainable Distributed Generation and Grid Access to All By 2022 https://www.npc.gov.np/images/category/SUDIGGAA_final_version.pdf [Date Accessed: August 10, 2019]

Wiener, Y., \& Klein, K. L. (1978).The Relationship Between Vocational Interests and Job Satisfaction: Reconciliation of Divergent Results. Journal of Vocational Behavior, 13(3), 298-304. doi:10.1016/0001-8791(78)90056-8 